\title{
Esterase-3 polymorphism in the sugarcane borer Diatraea saccharalis (Lepidoptera, Pyralidae)
}

\author{
Maria Claudia C. Ruvolo-Takasusuki, Maria de Fátima P.S. Machado and Hélio Conte \\ Departamento de Biologia Celular e Genetica, Universidade Estadual de Maringá, \\ Maringá, Paraná, Brazil
}

\begin{abstract}
The migration rate of esterases and their substrate specificity for 4-methylumbelliferyl esters (acetate, propionate, and butyrate) and $\alpha$ - and $\beta$-naphthyl esters were analyzed in Diatraea saccharalis by starch gel electrophoresis. Substrate preference of esterases was observed with Est-2 and Est-8 isozymes showing substrate specificity for 4-methylumbelliferyl esters and Est-4 isozyme showing specificity for 4-methylumbelliferyl butyrate and $\alpha$-naphthyl butyrate. Allele variation was detected at the Est-3 locus. Two alleles, $E s t-3^{F}$ and $E s t-3^{S}$, were identified in pupae with fluorogenic and ester-naphthyl substrates. Chi-square analysis showed no differences between the observed genotypic frequencies and those expected on the basis of Hardy-Weinberg frequencies for the Est-3 locus $\left(\chi^{2}=2.4\right.$; $\mathrm{p}<0.01)$. The negative value for the Wright's fixation index $(\mathrm{F}=-0.2096)$ calculated for the $D$. saccharalis population maintained under laboratory conditions indicates an excess of heterozygotes, however, the observed Hardy-Weinberg equilibrium indicates that in the laboratory the population of $D$. saccharalis behaved as if the moth were randomly mating in nature. The high level of heterozygosity at the Est-3 locus indicates also that this esterase may be a good genetic marker for studies of natural $D$. saccharalis populations.
\end{abstract}

Key words: esterase, genetic variability, isozymes, moth, sugarcane borer.

Received: January 4, 2002; accepted: March 14, 2002.

\section{Introduction}

The sugarcane borer Diatraea saccharalis (Fabricius 1724; Lepidoptera; Pyralidae) is an insect of great economic interest for the sugar-alcohol industry, because it occurs in sugarcane plantations where its larva damages sugarcane by boring into the stalks and reducing sucrose yield (Roc et al., 1981). Due to the peculiar ecological-climatic conditions prevalent in Brazil the sugarcane borer also increases the plants susceptibility to pathogens, allowing invasion by stalk-rot pathogens through larval tunnels, with infection by the red rot fungus (Physalospora tucumanensis) being particularly frequent.

In the warmer tropical climates, where perennial growth of sugarcane is not annually interrupted by spells of cold temperature, chemical control of the sugarcane borer is not recommended and, when practiced, is often ineffective (Roc et al., 1981). In Latin American countries, biological control is the most common method of suppressing $D$. saccharalis (William et al., 1969; Guagliumi, 1973), and hymenopteran and dipteran insect parasites have long been

Send correspondence to Maria de Fátima P.S. Machado. Departamento de Biologia Celular e Genetica, UEM, 87020-900 Maringá, PR, Brazil. E-mail: mfpsmachado@uem.br. extensively used for the biological control of $D$. saccharallis (see review in Conte, 1994). Although no data are available on the genetic structure of $D$. saccharalis populations, information on genetic variability is especially important for successful large-scale pest control programs and Johnson (1974), has pointed out that enzyme polymorphism may increase the opportunity for adaptability in organisms facing a variable environment.

The present study investigated the electrophoretic profiles of $D$. saccharalis esterases and obtained preliminary data on the genetic variability present in laboratory colonies of this species which are used for studies of biological control systems based on hymenopteran parasites. Esterase isozymes were chosen because their different forms are genetically determined by several loci, and a high frequency of genetic variants is usually detected in insect populations (Selander, 1976).

\section{Material and Methods}

Diatraea saccharalis individuals were obtained from a colony founded by ten adult females and two adult males moths, collected during March and April 1998 in the sugarcane fields of a local producer (The Santa Terezinha Factory, Maringá Region, Iguatemi District, northwest Paraná 
State, Brazil), established at the Department of Cell Biology and Genetics, State University of Maringá, Maringá, Paraná, Brazil. The moths had been collected in sugarcane fields infected with this borer and were transferred to the laboratory and maintained in a box $(20 \times 20 \times 10 \mathrm{~cm})$ for further breeding and the establishment of a $D$. saccharalis colony. To start the laboratory population the larvae, pupae and adult insects were maintained in a nylon-cloth covered wire-cage $(50 \times 40 \times 23 \mathrm{~cm})$ at $24 \pm 1{ }^{\circ} \mathrm{C}, 70 \pm 10 \% \mathrm{RH}$ and a $14 \mathrm{~h}$ photophase (Conte, 1994) and fed with the artificial diet developed by Hensley and Hammond (1968). After eight months, equivalent to about 4 generations of the moths (Conte, 1994), male and female pupae were collected at random and sexually identified under a stereoscopic microscope according to the method of Butt and Cantu (1962).

For electrophoretic analysis individual pupae were homogenized with a glass rod in an Eppendorf tube using $500 \mu \mathrm{L}$ of a $1 \%$ aqueous solution of $\beta$-mercaptoethanol and centrifuged at 3,000 rpm for $10 \mathrm{~min}$ at room temperature in a model Eppendorf 5417 centrifuge. The supernatants were absorbed with Whatman $\mathrm{n} .3$ paper strips $(5 \times 6 \mathrm{~mm})$ which were inserted vertically into a $14 \%$ starch gel prepared in $0.02 \mathrm{M}$ Tris- $\mathrm{HCl}$ buffer, $\mathrm{pH}$ 7.5. In the electrode chambers we used $0.3 \mathrm{M}$ Tris- $\mathrm{HCl}$ buffer, $\mathrm{pH}$ 7.5. Electrophoresis was carried out at $4{ }^{\circ} \mathrm{C}$ for about $4-5 \mathrm{~h}$, at $45 \mathrm{~mA}(9.5 \mathrm{~V} / \mathrm{cm}$ of gel). The esterase isozymes were stained by the methods of Hopkinson et al. (1973) and Coates et al. (1975) as modified by Ruvolo-Takasusuki et al. (1997), with 4-methylumbelliferyl (4-MUB) esters (acetate, propionate, and butyrate), and $\alpha$ - and $\beta$-naphthyl acetate and $\alpha$-naphthyl butyrate as substrates (Tashian, 1969; Ruvolo-Takasusuki et al., 1997). The 4-MUB ester substrate (4 mg) was dissolved separately in $500 \mu \mathrm{L}$ of acetone and the volume completed to $10 \mathrm{~mL}$ using double-distilled water. Following staining with 4-MUB acetate, propionate and butyrate, the gels were incubated for 30-60 min in a solution containing $50 \mathrm{~mL}$ of $0.05 \mathrm{M}$ sodium phosphate, $\mathrm{pH} 6.5,40 \mathrm{mg}$ Fast Blue RR salt and $4 \mathrm{~mL}$ of $1 \% \alpha$-naphthyl acetate, $\beta$-naphthyl acetate, and $\alpha$-naphthyl butyrate, respectively. The $\alpha$ and $\beta$-naphthyl esters were dissolved in $50 \mathrm{~mL}$ of acetone and the volume completed to $100 \mathrm{~mL}$ with double-distilled water. Stained gels were fixed in methanol: double-distilled water: acetic acid (5:5:1) for 3 min and washed with tap water.

\section{Results}

The staining techniques revealed the esterase isozyme patterns of the Diatraea saccharalis pupae, and indicated a total of eight esterase loci, referred to in the following text as Est-1 to Est-8. The isozymes Est-2 and Est-8 were substrate specific for 4-MUB esters (acetate, propionate, and butyrate) while Est-4 was specific to 4-methylumbelliferyl butyrate and $\alpha$-naphthyl butyrate (Figure 1).

Allelic variation was detected at the Est-3 locus, and two alleles, $E s t-3^{F}$ and $E s t-3^{S}$, were identified in pupae with 4-MUB acetate (Figure 1A) and $\alpha$ - and $\beta$-naphthyl acetate (Figure 2). The Est-4 isozyme detected with 4-MUB butyrate (Figure 1B) and $\alpha$-naphthyl butyrate was observed migrating between $E s t-3^{F}$ and $E s t-3^{S}$ alleles or sometime showing coincident migration with $E s t-3^{F}$ allele.

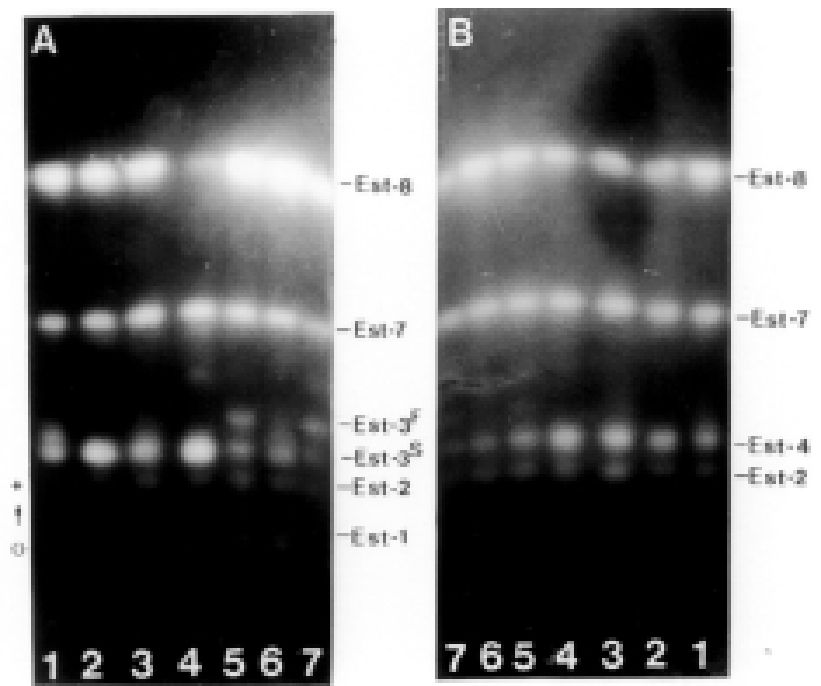

Figure 1 - Isoesterases of Diatraea saccharalis pupae on starch gel and Tris/citrate buffer, $\mathrm{pH} 7.0$ showing allelic variation for the Est-3 locus in A (4-methylumbelliferyl acetate) and the preference of the Est-2 and Est-8 isozymes for 4-methylumbelliferyl acetate and butyrate (A, B), and Est-4 isozyme for 4-methylumbelliferyl butyrate (B). Samples 1, 3, 5, 6, 7 correspond to the Est- $3^{\mathrm{F} / \mathrm{S}}$ isozyme phenotype; samples 2 and 4 correspond to the Est-3 $3^{\mathrm{S} / \mathrm{S}}$ isozyme phenotype.

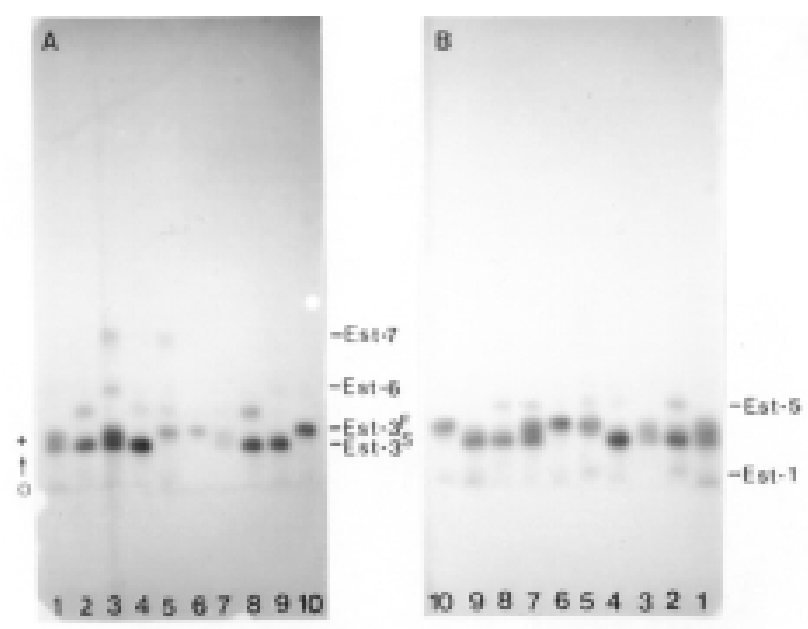

Figure 2 - Isoesterases of Diatraea saccharalis pupae on starch gel and Tris/citrate buffer, $\mathrm{pH} 7.0$ showing allelic variation for the Est 3 locus in A $(\alpha$-naphthyl acetate) and B ( $\beta$-naphthyl-acetate). Samples 1, 3 and 7 correspond to the Est- $3^{\mathrm{F} / \mathrm{S}}$ isozyme phenotype, samples 2, 4, 8 and 9 correspond to the Est- $3^{\mathrm{S} / \mathrm{s}}$ isozyme phenotype, and samples 5, 6 and 10 correspond to the Est- $3^{\mathrm{F} / \mathrm{F}}$ isozyme phenotypes. 
The number of males and females analyzed and the electrophoretic phenotypes of the Est-3 locus are listed in Table 1. Allele frequencies and mean heterozygosities for the Est-3 locus are listed in Table 2. Chi-squared analysis showed no differences between observed genotypic frequencies and the expected Hardy- Weinberg frequencies for the Est-3 locus $\left(\chi^{2}=2.4 ; \mathrm{p}<0.01\right.$; Table 3$)$, but the negative value for the Wright's fixation index (Wright, 1965) calculated for the $D$. saccharalis population maintained under laboratory conditions indicated an excess of heterozygotes.

\section{Discussion}

The present study is the first report to relate isozyme polymorphism in the Diatraea saccharalis species. The esterase isozyme patterns indicated a total of eight loci with substrate specificity for 4-MUB esters and $\alpha$-naphthyl butyrate, and allelic variation was detected at the Est-3 locus.

Table I - Number of Males and Females Analyzed and the Electrophoretic Phenotypes of the Est-3 locus in Diatraea saccharalis.

\begin{tabular}{llllll}
\hline & \multicolumn{4}{c}{ Phenotypes } \\
\cline { 2 - 5 } & \multicolumn{2}{c}{ Est-3 $^{\mathrm{F} / \mathrm{F}}$} & Est-3 $^{\mathrm{F} / \mathrm{S}}$ & Est-3 $^{\mathrm{S} / \mathrm{s}}$ & \multicolumn{2}{c}{ Total } \\
\hline Females & 5 & 19 & 5 & 29 \\
Males & 6 & 17 & 8 & 31 \\
Total & 11 & 36 & 13 & 60 \\
\hline
\end{tabular}

Table II - Allele Frequencies and Mean Heterozygosities for the Est-3 Locus in Male and Female Diatraea saccharalis.

\begin{tabular}{|c|c|c|c|c|}
\hline & \multicolumn{2}{|c|}{ Males } & \multicolumn{2}{|c|}{ Females } \\
\hline & Est $-3^{F}$ & $E s t-3^{S}$ & Est $-3^{F}$ & Est- $3^{S}$ \\
\hline Frequency & 0.4677 & 0.5323 & 0.5 & 0.5 \\
\hline \multicolumn{5}{|c|}{ Mean Heterozygosity } \\
\hline $\mathrm{H}_{0}$ & 0.5484 & & 0.6552 & \\
\hline \multirow[t]{4}{*}{$\mathrm{H}_{\mathrm{e}}$} & 0.4979 & & 0.5 & \\
\hline & \multicolumn{2}{|c|}{$\mathrm{H}_{0} /$ locus $=0.0686$} & \multicolumn{2}{|c|}{$\mathrm{H}_{0} /$ locus $=0.0819$} \\
\hline & \multicolumn{2}{|c|}{$\mathrm{H}_{\mathrm{e}} /$ locus $=0.0622$} & \multicolumn{2}{|c|}{$\mathrm{H}_{\mathrm{e}} /$ locus $=0.0625$} \\
\hline & \multicolumn{4}{|c|}{$\%$ polymorphic loci $=12.5$} \\
\hline
\end{tabular}

Table III - Comparison of the Genotypic Frequencies of the Est-3 Locus in the Population of Diatraea saccharalis.

\begin{tabular}{lccccc}
\hline Genotype & $\begin{array}{c}\text { Observed } \\
\text { number }\end{array}$ & $\begin{array}{c}\text { Expected } \\
\text { number }\end{array}$ & $\chi^{2}$ & df & $\mathrm{F}^{\mathrm{a}}$ \\
\hline Est-3 $^{\mathrm{F} / \mathrm{F}}$ & 11 & 14 & 0.64 & 1 & \\
Est-3 $^{\mathrm{S} / \mathrm{s}}$ & 13 & 16 & 0.56 & 1 & \\
Est-3 $^{\mathrm{S} / \mathrm{F}}$ & 36 & 30 & 1.2 & 1 & \\
& & & 2.40 (ns) & & -0.2096 \\
\hline
\end{tabular}

${ }^{\text {a }}$ Fixation index value (Wright, 1965) for a polymorphic locus. Ns: Not significant for $\mathrm{p}<0.01$.
Despite the method used to establish the $D$. saccharalis laboratory population which involved enforced inbreeding (Nei, 1975; Hedrich, 1983), the Hardy-Weinberg equilibrium test indicated that random-mating between males and females took place for at least 4 generations in this sub-population. Thus, it is possible to assume that the amount of genetic variation at the esterase loci of $D$. saccharalis remains constant in the presence of disturbing forces such as bottleneck or founder effects. The study of esterases in laboratory populations of $D$. saccharalis indicates that the data obtained by Conte (1994) on infestation control by hymenopteran parasites can be applied to natural populations. This is the most important aspect of our study because it shows that the information about genetic diversity in $D$. saccharalis laboratory populations can support biological control programs aimed at this species, since after being maintained for at least 4 generations under laboratory conditions the moths still behaved as if they were randomly mating in nature.

The Wright's fixation index value indicated an excess of heterozygotes in this $D$. saccharalis sub-population, reflecting overall outbreeding. The heterozygote excess observed for the Est-3 locus may be attributed to the method used to establish the laboratory population of $D$. saccharalis, since founder genotypes and random genetic drift are events which can produce higher than expected proportions of heterozygotes, and random drift is a frequent phenomenon in laboratory populations (Falconer and Mackay, 1996).

On the other hand, an overdominance effect can arise at the molecular level since the products of the two alleles can have different properties such as enzymatic activity, heat stability or activity optima for environmental factors such as temperature or $\mathrm{pH}$. The mixture of allozymes may therefore make the heterozygotes more versatile than homozygotes with single allozymes, i.e., they may be less susceptible to the impairment of enzyme function by environmental circumstances (Falconer and Mackay, 1996). Examples of esterase alleles related to specific environmental factors have been reported for other insect groups (Tsakas and Krimbas, 1970; Fournier et al., 1992, 1993; Ono et al., 1994; Dinardo-Miranda and Contel, 1996).

Although few proven cases of overdominance are known (Hartl and Clarck, 1989) and despite the fact that the fitness of the different esterases is unknown, overdominance may be an explanation for the slight excess of heterozygotes in the $D$. saccharalis sub-population. Heterozygote males and females may have a mating advantage which results in a stable polymorphism phenomenon.

The other important aspect of the present work is that the high level of heterozygosity at the Est-3 locus indicates that this esterase may be a good genetic marker for studies of the $D$. saccharalis populations. 


\section{References}

Butt BA and Cantu E (1962) Sex determination of lepidopterous pupae. ARS. USDA, Washington, pp 33-75.

Coates PM, Mestriner MA and Hopkinson DA (1975) A preliminary genetic interpretation of the esterase isozymes of human tissues. Ann. Hum. Genet. 39:1-20.

Conte H (1994) Morfologia do corpo gorduroso em larvas de Diatraea saccharalis (Lepidoptera; Pyralidae) não parasitadas pelo Cotesia flavipes (Hymenoptera: Braconidae). Doctoral Thesis, UNESP, Rio Claro, São Paulo, Brasil.

Dinardo-Miranda LL and Contel EPB (1996) Enzymatic variability in natural populations of Aedes aegypti (Diptera: Culicidae) from Brazil. J. Med. Entomol. 33:726-733.

Falconer DS and Mackay TFC (1996) Changes of gene frequency. Introduction to Quantitative Genetics. 4th edition. A.W. Longman Ltd., Harlow England, pp 23-77.

Fournier D, Bride JM, Hoffmann F and Karch F (1992) Acetylcholinesterase: two types of modifications confer resistance to insecticides. J. Biol. Chem. 267:14270-14274.

Fournier D, Mutero A, Pralavorio M and Bride JM (1993) Drosophila acetylcholinesterase mechanism of resistance to organophosphates. Chem. Biol. Interations 87:233-238.

Guagliumi P (1973) Pragas da Cana-de-açúcar. Nordeste do Brasil. Divulgação do M.I.C, Instituto do Açúcar e Álcool, Coleção Canavieira n. 10, Rio de Janeiro, 622 pp.

Hartl DL and Clarck AG (1989) Principles of Population Genetics. 2nd edition. Sinauer Associates, Inc., Suderland. USA, $682 \mathrm{pp}$.

Hedrick PW (1983) Genetics of Populations. Van Nostrand Reinhold Company, New York, 629 pp.

Hensley SD and Hammond AM (1968) Laboratory techniques for rearing the sugarcane borer on an artificial diet. J. Econ. Entomol. 61:1742-1743.
Hopkinson DA, Mestriner MA, Cortner J and Harris H (1973) Esterase-D: a new human polymorphism. Ann. Hum. Genet. 37:119-137.

Johnson GB (1974) Enzyme polymorphism and metabolism. Science 184:28-37.

Nei M (1975) Molecular Population Genetics and Evolution. North-Holland and American Elsevier, Amsterdam, 288 pp.

Ono M, Richman JS and Siegried BD (1994) Characterization of general esterases from susceptible and parathion-resistant strains of the greenbug (Homoptera: Aphidae). J. Econ. Entomol. 87:1430-1436.

Roc RM, Hammond Jr. AM, Reagan TE and Hensley SD (1981) A Bibliography of the Sugarcane Borer, Diatraea saccharalis (Fabricius), 1887-1980. U.S. Agricultural Research Service (Southern Region), U.S. Department of Agriculture, New Orleans, $101 \mathrm{pp}$.

Ruvolo-Takasusuki MCC, Del Lama MA and Soares AEE (1997) Genetic characterization of a new Apis mellifera esterase. Apidologie 28:259-267.

Selander RK (1976) Genetic variation in natural populations. In: Ayala FJ (ed) Molecular Evolution. Sinauer Associates, Inc., Suderland, Massachusetts, pp 277.

Tashian RE (1969) The esterases and carbonic anhydrases of human erythrocytes. In: Yunis JJ (ed) Biochemical Methods in Red Cell Genetics. Academic Press, pp 307-336.

Tsakas S and Krimbas CB (1970) The genetics of Dacus oleae. IV. Relation between adult esterase genotypes and survival to organophosphate insecticides. Evolution 24:807-815.

William JR, Metcalfe JR, Mungomery RW and Mathes R (1969) Pests of Sugar Cane. Elsevier Publ. Co., New York, N.Y, $568 \mathrm{p}$.

Wright S (1965) The interpretation of population structure by F-statistics with special regard to systems of mating. Evolution 19:395-420. 